\title{
Non-destructive measurement of leaf area and leaf pigments in feijoa trees
}

\author{
Marcos R. Sachet ${ }^{1}$, Idemir Citadin ${ }^{2}$, Marieli T. Guerrezi ${ }^{3}$, Rafael H. Pertille ${ }^{4}$, Joel Donazzolo ${ }^{5}$ \\ \& Rubens O. Nodari ${ }^{6}$
}

${ }^{1}$ Universidade Federal de Roraima/Escola Agrotécnica. Boa Vista, RR. E-mail: marcos.sachet@ufrr.br (Corresponding author) - ORCID: 0000-00020395-2475

${ }^{2}$ Universidade Tecnológica Federal do Paraná/Departamento de Agronomia/Programa de Pós-Graduação em Agronomia. Pato Branco, PR. E-mail: idemir@utfpr.edu.br - ORCID: 0000-0001-9416-2761

${ }^{3}$ Universidade Federal de Roraima/Curso de Agronomia. Boa Vista, RR. E-mail: marieliguerrezi@hotmail.com - ORCID: 0000-0003-3314-4046

${ }^{4}$ Universidade Tecnológica Federal do Paraná/Departamento de Agronomia. Pato Branco, PR. E-mail: henriquepertille@gmail.com - ORCID: 00000002-4888-2001

${ }^{5}$ Universidade Tecnológica Federal do Paraná/Curso de Agronomia/Programa de Pós-Graduação em Agroecossistemas. Dois Vizinhos, PR. E-mail: joel@utfpr.edu.br - ORCID: 0000-0002-6331-0378

${ }^{6}$ Universidade Federal de Santa Catarina/Centro de Ciências Agrárias/Programa de Graduação em Recursos Genéticos Vegetais. Florianópolis, SC. E-mail: rubens.nodari@ufsc.br - ORCID: 0000-0002-8884-2426

\begin{abstract}
Leaf area $\left(\mathrm{cm}^{2}\right.$ per leaf) and leaf pigment content are important traits that can be used to better understand a plants physiology. In this study, empirical non-destructive models for leaf area and leaf pigment based on the leaf dimensions, length (L) and width (W) in centimeters, and chlorophyll meter readings were developed for feijoa (Acca sellowiana). The experiment was carried out during January 2016 using five-year-old trees of 60 genotypes, grown under field conditions in the state of Paraná, Brazil. The proposed leaf area (LA) model was $\mathrm{LA}=0.0022 \mathrm{~L}^{3}+0.1482 \mathrm{~W}^{2}+0.6159 \mathrm{LW}+0.1076\left(\mathrm{R}^{2}=0.99\right)$. Three current leaf area models found in the literature were also assessed. All of the already created models were less accurate than the model proposed in this article. The proposed leaf pigment models were based on the Falker Chlorophyll Index for Chlorophyll a (A) and b (B), these were Chl $=2.564 \mathrm{~A}+13.098 \mathrm{~B}-42.605$ $\left(\mathrm{R}^{2}=0.94\right), \mathrm{Chl}_{\mathrm{b}}=1.538 \mathrm{~A}+3.287 \mathrm{~B}+8.847\left(\mathrm{R}^{2}=0.86\right)$ and Carotenoids $=0.947 \mathrm{~B}+8.943\left(\mathrm{R}^{2}=0.88\right)$ expressed as $\mu \mathrm{mol} \mathrm{m}{ }^{-2}$ of leaf blade. In conclusion, the proposed models in this study were shown to be a reliable non-destructivel way of estimating A. sellowiana leaf area and leaf pigment.
\end{abstract}

Key words: indirect estimates, pineapple guava, Acca sellowiana

\section{Método não-destrutivo para estimar área foliar e pigmentos foliares em feijoa}

RESUMO: A área foliar ( $\mathrm{cm}^{2}$ por folha) e o conteúdo de pigmentos foliares são importantes características usadas para melhor entender a fisiologia das plantas. Neste estudo, modelos não-destrutivos para área foliar e conteúdo de pigmentos baseados no comprimento (L) e na largura (W) da folha, e na leitura do teor de clorofila, foram desenvolvidos para feijoa (Acca sellowiana). O experimento foi desenvolvido durante o mês de janeiro de 2016 usando 60 genótipos com cinco anos de idade, cultivados no estado do Paraná, Brasil. A proposta de modelo para área foliar (LA) foi $\mathrm{LA}=0,0022 \mathrm{~L}^{3}+0,1482 \mathrm{~W}^{2}+0,6159 \mathrm{LW}+0,1076\left(\mathrm{R}^{2}=0,99\right)$. Três modelos encontrados na literatura também foram analisados. Todos esses modelos tiveram menor acurácia que o modelo proposto por este estudo. Os modelos propostos para estimar os pigmentos foliares foram baseados no Falker Chlorophyll Index para clorofila a (A) and b (B), sendo estes Chl $=2,564 \mathrm{~A}+$ $13,098 \mathrm{~B}-42,605\left(\mathrm{R}^{2}=0,94\right), \mathrm{Chl}_{\mathrm{b}}=1,538 \mathrm{~A}+3,287 \mathrm{~B}+8,847\left(\mathrm{R}^{2}=0,86\right)$ e carotenoides $=0,947 \mathrm{~B}+8,943$ $\left(\mathrm{R}^{2}=0,88\right)$ expressos como $\mu \mathrm{mol} \mathrm{m}{ }^{-2}$ de lâmina folha. Conclui-se que os modelos propostos neste estudo se mostraram confiáveis métodos não destrutíveis para estimar a área foliar e o conteúdo de pigmento foliares em A. sellowiana.

Palavras-chave: estimativas indiretas, 'pineapple'-guava, Acca sellowiana 


\section{INTRODUCTION}

Feijoa (Acca sellowiana (O. Berg) Burret) is a fruit tree native to the highlands of Southern Brazil and Northeastern Uruguay and it has spread worldwide over the last 100 years (Sharpe et al., 1993). In Brazil the cultivated area of feijoa is increasing (Donazzolo et al., 2015), with cultivars having been created (Ducroquet et al., 2007, 2008). However, feijoa trees have shown good adaptability to subtropical regions and are also cultivated in the United States of America, New Zealand, Colombia, Australia, Turkey, and China (Thorp \& Bieleski, 2002; Beyhan \& Eyduran, 2011; Xiong et al., 2016).

To advance in feijoa cultivation plant ecophysiology studies are necessary, including those relating to leaf area (LA) and pigment content (LP). These two traits are important in order to define the plasticity and adaptability of feijoa trees to distinct environments, such as agroforestry systems (Donazzolo et al., 2014) and under the effects of water stress (Baracaldo \& Gutiérrez, 2014). In other species, LA and LP have been related to fertilization, rootstocks (Sachet et al., 2015), pest damage (Huang et al., 2014) and shading effects (Huang et al., 2015). Indirect methods for quantifying LA and LP are useful, principally when equipment and/or analytical reagent for direct measurement are not available or nondestructive measurements are required, such as under field conditions or low plant density growing in pots for controlled experiments (Peksen, 2007).

One of the most frequently used indirect methods for estimating LA are mathematical models involving leaf length and/or leaf width (Peksen, 2007). While LP content can be related to chlorophyll meter readings using a portable Clorofilog-1030 (Brito et al., 2011; Rigon et al., 2012a, b; 2013; Conforto et al., 2014; Kaspary et al., 2014). For LA, the mathematical models are species-specific (Demirsoy, 2009), although they can also vary among cultivars (Buttaro et al., 2015). The same is true for LP models (Parry et al., 2014). Therefore, besides developing new models, it is also necessary to test the available models developed under different experimental conditions. LA models under contrasting conditions have been developed for feijoa trees (Mielke et al., 1995; Casierra-Posada et al., 2008; Huang et al., 2015). However, LP models were not found. Thus, the objectives of this study were to develop and validate LA and LP estimation models for A. sellowiana.

\section{Material ANd Methods}

The leaf samples from 60 A. sellowiana genotypes were collected in January 2016. The orchard was established in 2011 at the Federal University of Technology - Paraná (UTFPR), Experimental Station in Pato Branco (26 $10 \mathrm{~S} ; 52^{\circ} 41 \mathrm{~W}$, $760 \mathrm{~m}$ a.s.l.), Paraná State, Brazil. The local climate is classified as humid subtropical, Cfa by the Köppen's Classification (Alvares et al., 2013). The average annual temperature is between 18 and $19{ }^{\circ} \mathrm{C}$, and the precipitation is well distributed in the months of the year, exceeding $1800 \mathrm{~mm}$ annually. The spacing between trees was 3 x 5 m with "Quad-V" canopy training. The plants had an average height of $202.9( \pm 29.9) \mathrm{cm}$. The genotypes used were descended from crosses between Nonante (Ducroquet et al., 2008), Alcântra and Helena (Ducroquet et al., 2007) cultivars.

Forty completely expanded and healthy leaves harvested from each genotype were used for model development and 10 leaves were used for the repeatability analysis. Leaf dimensions (L, Length; W, Width; LA, Leaf Area) without petiole were determined, using the ImageJ software, from scanned blackwhite images with a 39.37 pixels $\mathrm{cm}^{-1}$ resolution (Figure 1).

The relationships were evaluated by fitting regression models, using the multiple regression procedure of GENES Software (Cruz, 2013), and the stepwise elimination of variables with corresponding $\mathrm{p}$-values greater than 0.05 . In addition, the internal validity of the model was assessed by the adjusted coefficient of determination $\left(\mathrm{R}^{2}\right)$ and mean absolute error (MAE). The reproducibility was determined by the concordance correlation coefficient (CCC) of Lin (2000) between the predicted and actual LA values. Modeling was run using LA as the dependent variable, while the independent variables were $\mathrm{L}^{\mathrm{n}}, \mathrm{W}^{\mathrm{n}}, \mathrm{L}^{\mathrm{n}} \mathrm{W}^{\mathrm{n}}$ and $\mathrm{L}^{\mathrm{n}} / \mathrm{W}^{\mathrm{n}}$, with $\mathrm{n}$ values $=1,2$ and 3.

A repeatability analysis was performed to evaluate which of the LA models demonstrated predicted data similar to the actual data. In this case, the data for the dimensions of 10 leaves collected from 60 feijoa tree genotypes were submitted to one-way ANOVA, using GENES Software. The repeatability coefficient, the number of measurements needed to achieve 90, 95 and 99\% accuracy, the F-value, and the coefficient of variation $(\mathrm{CV})$ were all also calculated.

Three LA feijoa models developed under different experimental and climate conditions using distinct genotypes were also tested. The first, developed by Mielke et al. (1995), was based on native trees grown in the state of Rio Grande do Sul, Southern Brazil, under a subtropical climate (Köppen Cfa). The second model, proposed by Casierra-Posada et al. (2008), used trees from Tunja, an Andean region of Colombia, under a subtropical highland climate (Köppen Cfb). The third model, proposed by Huang et al. (2015), was developed using five-year-old trees in Sichuan Province, Southwestern China, a climate likely to be humid subtropical (Köppen Cfa or Cwa), with strong monsoonal influences. All three model equations are presented in Table 1.

To determine the pigment content, leaf discs with an area of $1.04 \mathrm{~cm}^{2}$ were excised from 60 leaves. Leaves of different colors were used with the aim of increasing the model spectrum.
A.

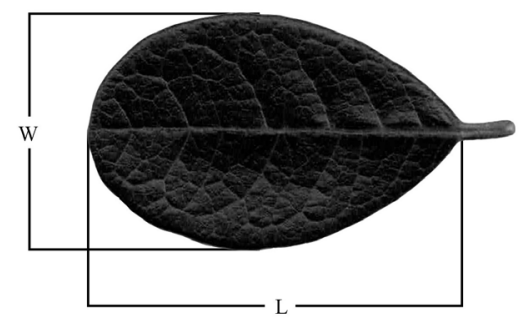

B.

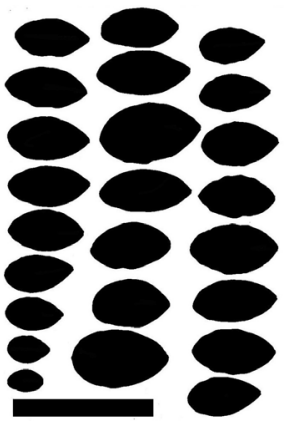

Figure 1. Feijoa (Acca sellowiana) leaf, with markings indicating from which points the leaf length $(L)$ and width $(W)$ measurements were taken $(A)$ and scanned black-white images for measurement using the ImageJ software, the black rectangle was the internal $10 \mathrm{~cm}$ reference $(\mathrm{B})$ 
The colors of the leaves were assessed individually using a ClorofiLOG- $1030^{\circ}$ portable chlorophyll meter (Brazilian Patent Office: PI075579-0 published in 2008). The samples were placed individually in test tubes, sheltered from the light and then $5 \mathrm{~cm}^{3}$ of DMSO was added. The test tubes were incubated for $60 \mathrm{~min}$ at $60^{\circ} \mathrm{C}$ to complete disc bleaching. After being left to cool at room temperature, the absorbances of the extracts were determined for the wavelengths 470, 649.1 and $665.1 \mathrm{~nm}$ (Shimadzu, UV-1800). The equations described by Wellburn (1994) were used for the quantification of chlorophylls a and $\mathrm{b}$, the total chlorophyll $(\mathrm{a}+\mathrm{b})$ and carotenoid contents. The values were expressed in $\mu \mathrm{mol} \mathrm{m} \mathrm{m}^{-2}$ of leaf blade, where Chl a $=892.3 \mathrm{~g} \mathrm{~mol}^{-1}, \mathrm{Chl} \mathrm{b}=906.3 \mathrm{~g} \mathrm{~mol}^{-1}$ and Car $=552.8 \mathrm{~g} \mathrm{~mol}^{-1}$ (common molar weight for $\infty$ - and $\beta$-carotenes).

For the LP mathematical models, pigment contents extracted by the classical method were used as the dependent variables, while FCI (Falker Chlorophyll Index) readings for Chl a (FCIa), Chl b (FCIb) and Chl total (FCIa + b) were used as the independent variables. The statistical analysis employed was the same as that used in the development of the LA models.

\section{Results AND Discussion}

The measured leaf dimensions were between the following intervals: 2.1 to $9.5 \mathrm{~cm}$ for $\mathrm{L}, 1.1$ to $5.8 \mathrm{~cm}$ for $\mathrm{W}$ and 1.7 to 33.6 $\mathrm{cm}^{2}$ for LA. The LA models were developed using either L (Mod. 1), W (Mod. 2) or both (Mod. 3). These models and the three published LA models are presented in Table 1. The strengthof-agreement of the CCC-Value, as defined by McBride (2007), the Mod.3 and Casierra-Posada et al. (2008) models can be considered almost perfect, the Mod.2 and Mielke et al. (1995) models as substantial, while the Mod.1 and Huang et al. (2015) models can be considered as moderate as a function of the degree of equivalence between the estimated and actual data. Mod.3 also showed the smallest MAE (1.6\%) and the highest adjusted coefficient of determination $\left(\mathrm{R}^{2}=0.996\right)$.

For the actual LA data, the repeatability coefficient was $0.71, \mathrm{R}^{2}=96.1 \%, \mathrm{~F}=25.5$ and $\mathrm{CV}=11.8 \%$ and it required up

Table 1. Fitted models for the leaf area (LA, $\mathrm{cm}^{2}$ per leaf) of Acca sellowiana, adjusted coefficient of determination $\left(R^{2}\right)$, mean absolute error (MAE) and concordance correlation coefficient (CCC), according to the dimensions of the leaves: width (W) and length $(\mathrm{L})$ of leaf blade

\begin{tabular}{|c|c|c|c|}
\hline Equation & $\mathrm{R}^{2}$ & $\begin{array}{c}\text { MAE } \\
(\%)\end{array}$ & CCC \\
\hline \multicolumn{4}{|l|}{ Mod. 1} \\
\hline$A F=-0.0118 L^{3}+0.5324 L^{2}-0.2568$ & 0.880 & 8.8 & 0.936 \\
\hline \multicolumn{4}{|l|}{$S D=(0.027)^{\star \star \star}(0.003)^{\star \star \star}$} \\
\hline \multicolumn{4}{|l|}{ Mod. 2} \\
\hline$A F=-0.0759 W^{3}+1.475 W^{2}-0.1678$ & 0.927 & 7.0 & 0.962 \\
\hline \multicolumn{4}{|l|}{$S D=(0.008)^{\star \star \star}(0.048)^{\star \star \star}$} \\
\hline \multicolumn{4}{|l|}{ Mod. 3} \\
\hline$A F=0.0022 L^{3}+0.1482 W^{2}+0.6159 W L+0.1076$ & 0.996 & 1.6 & 0.998 \\
\hline \multicolumn{4}{|l|}{$\mathrm{SD}=(0.0005)^{\star \star \star}(0.013)^{\star \star \star}(0.153)^{\star \star \star}$} \\
\hline \multicolumn{4}{|l|}{ Mielke et al. (1995) } \\
\hline$A F=0.856 \mathrm{WL}-2.115$ & 0.967 & 5.0 & 0.986 \\
\hline \multicolumn{4}{|l|}{ Casierra-Posada et al. (2008) } \\
\hline $\mathrm{AF}=0.000111(\mathrm{WL})^{3}-0.007734(\mathrm{WL})^{2}+0.868539 \mathrm{WL}$ & 0.985 & 4.3 & 0.992 \\
\hline \multicolumn{4}{|l|}{ Huang et al. (2015) } \\
\hline $\mathrm{AF}=0.630 \mathrm{WL}+0.333$ & 0.838 & 11.6 & 0.912 \\
\hline
\end{tabular}

to 41 measurements to reach an accuracy of $99 \%$ (Table 2). Considering these data, only Mod.1 significantly changed the actual LA data structure, showing a lower repeatability (0.59), a lower F-value (15.3) and an increasing number of measurements needed for each level of accuracy desired (up to 70).

According to the results, the LA estimated by Mod.3 (Table 2) was shown to be the most adequate for studying Brazilian genotypes due to its effectiveness. Despite their lower levels of accuracy, the models proposed by Mielke et al. (1995) and Casierra-Posada et al. (2008) were also shown to be adequate. In the present study, it was verified that the lowest strengthof-agreement for the CCC-Value was found when only one leaf dimension (Mod.1 and 2) was used. This result is in agreement with those found in the literature for the majority of the LA models, since they are based on two leaf dimensions for several species (Demirsoy, 2009). In addition, models that give a low quality estimate of LA, which are based on one leaf dimension, can result in data interpretation errors, as was observed with Mod.1, which had a lower F-value and tended to present statistical type II errors (incorrectly retaining a false null hypothesis).

For LP modeling, the FCI readings ranged from 7.5 to 42.5 for Chl a and 1.6 to 42.8 for Chl b. The CCC-values for the Chl $\mathrm{a}$ and $\mathrm{Chl} \mathrm{a}+\mathrm{b}$ models indicated that the strength-of-agreement was substantial whereas for the $\mathrm{Chl} b$ and Car models the values were moderate. The adjusted coefficient of determination varied from 0.86 to 0.94 , and the MAE values were very similar among the LP models (10.7 to $11.5 \%$ - Table 3 ).

Table 2. The estimation of repeatability coefficient (̌r), number of measurements needed $\left(\eta_{0}\right)$ for 90, 95 and $99 \%$ accuracy, and $F$ value for leaf area (LA, $\mathrm{cm}^{2}$ per leaf) obtained from mathematical models and the actual LA for Acca sellowiana

\begin{tabular}{lccccccc} 
Model & $\check{\mathbf{r}}$ & $\mathbf{R}^{2}$ & $\begin{array}{c}\boldsymbol{\eta}_{\mathbf{0}} \\
\mathbf{( 9 0 \% )}\end{array}$ & $\begin{array}{c}\boldsymbol{\eta}_{\mathbf{0}} \\
\mathbf{( 9 5 \% )}\end{array}$ & $\begin{array}{c}\boldsymbol{\eta} \\
\mathbf{( 9 9 \% )}\end{array}$ & $\mathbf{F}$ & $\begin{array}{c}\mathbf{C V} \\
\mathbf{( \% )}\end{array}$ \\
\hline Mod. 1 & 0.59 & 93.5 & 7 & 14 & 70 & 15.3 & 13.0 \\
Mod. 2 & 0.68 & 95.5 & 5 & 10 & 47 & 22.1 & 12.2 \\
Mod. 3 & 0.69 & 95.7 & 4 & 8 & 45 & 23.5 & 12.0 \\
Mod. 4* & 0.69 & 95.7 & 5 & 9 & 45 & 23.3 & 13.0 \\
Mod. 5* $^{*}$ & 0.68 & 95.5 & 5 & 9 & 47 & 22.3 & 11.5 \\
Mod. 6* $^{*}$ & 0.69 & 95.7 & 5 & 9 & 45 & 23.3 & 11.6 \\
Actual LA & 0.71 & 96.1 & 4 & 8 & 41 & 25.5 & 11.8 \\
\hline
\end{tabular}

* Mod. 4 - Mielke et al. (1995); Mod. 5 - Casierra-Posada et al. (2008) and Mod. 6 - Huang et al. (2015)

Table 3. Models for chlorophyll and carotenoids ( $\mu \mathrm{mol} \mathrm{m}^{-2}$ ) contents in Acca sellowiana leaves and their respective adjusted coefficient of determination $\left(\mathrm{R}^{2}\right)$, mean absolute error (MAE) and concordance correlation coefficient (CCC) according to the Falker Chlorophyll Index value (Clorofilog-1030) for chlorophyll a $(A)$ and $b(B)$

\begin{tabular}{|c|c|c|c|c|}
\hline Model & Equation & $\mathbf{R}^{2}$ & $\begin{array}{l}\text { EAM } \\
(\%)\end{array}$ & CCC \\
\hline \multirow[t]{2}{*}{ Chl a } & $2.564 A+13.098 B-42.605$ & 0.94 & 11.5 & 0.97 \\
\hline & $\mathrm{SD}=(1.286)^{\star}(0.830)^{\star \star *}$ & & & \\
\hline \multirow[t]{2}{*}{ Chl b } & $1.538 \mathrm{~A}+3.287 \mathrm{~B}+8.847$ & 0.86 & 11.3 & 0.93 \\
\hline & $S D=(0.582)^{\star}(0.376)^{\star * *}$ & & & \\
\hline \multirow[t]{2}{*}{$\mathrm{Chl} a+b$} & $4.102 A+16.385 B-33.758$ & 0.93 & 11.5 & 0.96 \\
\hline & $\mathrm{SD}=(1.810)^{\star}(1.168)^{\star \star \star}$ & & & \\
\hline \multirow[t]{2}{*}{ Car } & $0.947 B+8.943$ & 0.88 & 10.7 & 0.94 \\
\hline & $\mathrm{SD}=(0.045)^{\star \star \star}$ & & & \\
\hline
\end{tabular}

SD - Standard deviation associated with the angular coefficient; Significant angular coefficient of the model for ${ }^{* * *} p$-value $<0.001$ and ${ }^{*} p$-value $<0.05$ 
The Clorofilog-1030 device is patented and has been commercially available since 2008. Since then, LP content estimation from FCI readings has been applied for Cotton plants - Gossypium hirsutum (Brito et al., 2011), Castor oil plant - Ricinus communis (Rigon et al., 2012b), Sesame - Sesamum indicum (Rigon et al., 2012a), Jatropha - Jatropha curcas (Rigon et al., 2013), Rubber tree - Hevea brasiliensis (Conforto et al., 2014), Italian ryegrass - Lolium multiflorum (Kaspary et al., 2014), and six Brazilian Atlantic Forest native trees (Vieira Silva, 2014).

LP models of the species listed above were related to FCI $a+b$, except in Conforto et al. (2014) and Vieira Silva (2014), who used individual FCI $\mathrm{a}, \mathrm{FCI} \mathrm{b}$ and FCI $\mathrm{a}+\mathrm{b}$ readings. In the present study, the modeling was based on FCIa and FCIb combined into the same model, as was observed in Wellburn (1994), who used equations that included both absorbance readings to estimate $\mathrm{Chl}$ content, since there is mutual interference between the two Chl wavelengths. This inference was confirmed by stepwise regression through the inclusion of FCIa and FCIb variables if their corresponding p-values were smaller than 0.05 .

The models obtained can be used to facilitate additional studies on feijoa in Brazil, the main area of genetic diversity of this species, especially in feijoa physiological studies and for other research areas that aim to screen genotypes and increase yield and cultivation system efficiency. Thus, studies on adequate pruning and thinning, which are essential for optimizing management practices, could be made easier with the additional models adjusted for Brazilian conditions and genotypes. In addition, the two traits studied could be taken into account as new selection criteria in the development of new cultivars, due to their ease of use.

\section{Conclusions}

1. The best leaf area models for feijoa were based on both leaf length and width. The proposed leaf area (LA) model was $\mathrm{LA}=0.0022 \mathrm{~L}^{3}+0.1482 \mathrm{~W}^{2}+0.6159 \mathrm{LW}+0.1076$.

2. For leaf pigment models both FCIa and FCIb should be included. The proposed leaf pigment models were: $\mathrm{Chl}_{\mathrm{a}}=$ $2.564 \mathrm{~A}+13.098 \mathrm{~B}-42.605, \mathrm{Chl}_{\mathrm{b}}=1.538 \mathrm{~A}+3.287 \mathrm{~B}+8.847$ and Carotenoids $=0.947 \mathrm{~B}+8.943$ expressed as $\mu \mathrm{mol} \mathrm{m} \mathrm{m}^{-2}$ of leaf blade.

3. Due to the high quality of the estimated data, the present models are useful for predicting leaf area and leaf pigment nondestructively and facilitate additional physiological, pruning and thinning studies on feijoa.

\section{Literature Cited}

Alvares, C. A.; Stape, J. L.; Sentelhas, P. C.; Gonçalves, J. L. de M.; Sparovek, G. Köppen's climate classification map for Brazil. Meteorologische Zeitschrift, v.22, p.711-728, 2013. https://doi. org/10.1127/0941-2948/2013/0507

Baracaldo, F. J. P.; Gutiérrez, M. C. Aspectos ecofisiológicos de la feijoa (Acca sellowiana Berg.) bajo condiciones de riego y déficit hídrico. Revista U.D.C.A. Actualidad \& Divulgación Científica, v.17, p.381-390, 2014.
Beyhan, O.; Eyduran, S. P. Determination of promising native Feijoa (Feijoa sellowiana Berg.) genotypes from Sakarya Region in Turkey. Scientific Research and Essays, v.6, p.4104-4108, 2011. https://doi.org/10.5897/SRE11.558

Brito, G. G.; Sofiatti, V.; Brandão, Z. N.; Silva, V. B.; Silva, F. M.; Silva, D. A. Non-destructive analysis of photosynthetic pigments in cotton plants. Acta Scientiarum. Agronomy, v.33, p.671-678, 2011. https://doi.org/10.4025/actasciagron.v33i4.10926

Buttaro, D.; Rouphael, Y.; Rivera, C. M.; Colla, G.; Gonnella, M. Simple and accurate allometric model for leaf area estimation in Vitis vinifera L. genotypes. Photosynthetica, v.53, p.342-348, 2015. https://doi.org/10.1007/s11099-015-0117-2

Casierra-Posada, F.; Peña, Z. G. R.; Peña-Olmos, J. E. Estimación indirecta del área foliar en Fragaria vesca L., Physalis peruviana L., Acca sellowiana (Berg.) Burret, Rubus glaucus L., Passiflora mollissima (Kunth) L. H. Bailey y Ficus carica L. Revista U.D.C.A. Actualidad \& Divulgación Científica, v.11, p.95-102, 2008.

Conforto, E. C.; Cornélio, M. L.; Andreoli, R. P.; Gonçalves, E. C. P. Validação das unidades arbitrárias do teor de clorofilas obtido em folhas intactas de seringueira. Revista Agro@mbiente On-line, v.8, p.288-292, 2014.

Cruz, C. D. Genes: A software package for analysis in experimental statistics and quantitative genetics. Acta Scientiarum. Agronomy, v.35, p.271-276, 2013. https://doi.org/10.4025/actasciagron. v35i3.21251

Demirsoy, H. Leaf area estimation in some species of fruit tree by using models as a non-destructive method. Fruits, v.64, p.45-51, 2009. https://doi.org/10.1051/fruits/2008049

Donazzolo, J.; Ornellas, T. S.; Bertoldo, J. G.; Nodari, R. O. Performance of segregating populations of feijoa cultivated under the agroforestry systems in southern Brazil. African Journal of Agricultural Research, v.9, p.3305-3312, 2014.

Donazzolo, J.; Ornellas, T. S.; Bizzocchi, L.; Vilperte, V.; Nodari, R. O. O armazenamento refrigerado prolonga a viabilidade de sementes de goiabeira-serrana. Revista Brasileira de Fruticultura, v.37, p.748-754, 2015. https://doi.org/10.1590/0100-2945-179/14

Ducroquet, J. P. H. J.; Nunes, E. da C.; Guerra, M. P.; Nodari, R. O. Novas cultivares brasileiras de goiabeira serrana: SCS 414-Mattos e SCS 415-Nonante. Agropecuária Catarinense, v.21, p.79-82, 2008.

Ducroquet, J. P. H. J.; Santos, K. L. dos; Andrade, E. R. de; Boneti, J. I. da S.; Bonin, V.; Nodari, R. O. As primeiras cultivares brasileiras de goiabeira serrana: SCS 411 Alcântara e SCS 412 Helena. Agropecuária Catarinense, v.20, p.77-80, 2007.

Huang, T. I.; Reed, D. A.; Perring, T. M.; Palumbo, J. C. Feeding damage by Bagrada hilaris (Hemiptera: Pentatomidae) and impact on growth and chlorophyll content of Brassicaceous plant species. Arthropod-Plant Interactions, v.8, p.89-100, 2014. https://doi. org/10.1007/s11829-014-9289-0

Huang, Y.; Wang, D.; Ren, S. X.; Fu, Y. J.; Liu, H. W. Predicting models of height and $\mathrm{DBH}$, specific leaf area, crown volume and LAI for Feijoa sallow. Guangdong Agricultural Sciences, v.7, p.151-155, 2015.

Kaspary, T. E.; Lamego, F. P.; Peruzzo, S. T.; Pagliarini, I. B.; Rigon, C. A. G. Pigmentos fotossintéticos em azevém suscetível e resistente ao herbicida glyphosate. Ciência Rural, v.44, p.1901-1907, 2014. https://doi.org/10.1590/0103-8478cr20131177

Lin, L. A note on the concordance correlation coefficient. Biometrics, v.56, p.324-325, 2000. 
McBride, G. B. Equivalence measures for comparing the performance of alternative methods for the analysis of water quality variables. Hamilton: National Institute of Water \& Atmospheric Research Ltd, 2007. 29p.

Mielke, M. S.; Hoffmann, A.; Endres, L.; Fachinello, J. C. Comparação de métodos de laboratório e de campo para a estimativa da área foliar em fruteiras silvestres. Scientia Agricola, v.52, p.82-88, 1995. https://doi.org/10.1590/S0103-90161995000100015

Parry, C.; Blonquist Junior, J. M.; Bugbee, B. In situ measurement of leaf chlorophyll concentration: Analysis of the optical/absolute relationship. Plant, Cell and Environment, v.37, p.2508-2520, 2014. https://doi.org/10.1111/pce.12324

Peksen, E. Non-destructive leaf area estimation model for faba bean (Vicia faba L.). Scientia Horticulturae, v.113, p.322-328, 2007. https://doi.org/10.1016/j.scienta.2007.04.003

Rigon, J. P. G.; Beltrão, N. E. de M.; Capuani, S.; Brito Neto, J. F. de; Silva, F. V. D. de F. Análise não destrutiva de pigmentos fotossintéticos em folhas de gergelim. Revista Brasileira de Engenharia Agrícola e Ambiental, v.16, p.258-261, 2012a. https:// doi.org/10.1590/S1415-43662012000300004

Rigon, J. P. G.; Capuani, S.; Beltrão, N. de E. M.; Brito Neto, J. F. de; Sofiatti, V.; França, F. V. de. Non-destructive determination of photosynthetic pigments in the leaves of castor oil plants. Acta Scientiarum. Agronomy, v.34, p.325-329, 2012b. https://doi. org/10.4025/actasciagron.v34i3.13872
Rigon J. P. G.; Capuani, S.; Brito Neto, J. F. de; Beltrão, N. E. de M. Indirect measurement of photosynthetic pigments in the leaves of Jatropha curcas. Semina: Ciências Agrárias, v.34, p.669-674, 2013. https://doi.org/10.5433/1679-0359.2013v34n2p669

Sachet, M. R.; Penso, G. A.; Pertille, R. H.; Guerrezi, M. T.; Citadin, I. Estimativa da área foliar de pessegueiro por método nãodestrutivo. Ciência Rural, v.45, p.2161-2165, 2015. https://doi. org/10.1590/0103-8478cr20140185

Sharpe, R. H.; Sherman, W. B.; Miller, E. P. Feijoa history and improvement. Proceedings of Florida State Horticultural Society, v.106, p.134-139. 1993.

Thorp, G.; Bieleski, R. Feijoas: Origins, cultivation and uses. Auckland: David Bateman, 2002. 87p.

Vieira Silva, D. Métodos não destrutivos para estimativas de clorofilas como indicadores da qualidade de mudas de espécies florestais. Ilhéus: Universidade Estadual de Santa Cruz, 2014. 62p. Dissertação Mestrado

Xiong, H.; Zou, F.; Yuan, D.; Zhang, X.; Tan, X. Orthogonal test design for optimising the culture medium for in vitro pollen germination of feijoa (Acca sellowiana cv. Unique). New Zealand Journal of Crop and Horticultural Science, v.44, p.192-202, 2016. https:// doi.org/10.1080/01140671.2016.1174945

Wellburn, A. R. The spectral determination of chlorophylls a and b, as well as total carotenoids, using various solvents with spectrophotometers of different resolution. Journal of Plant Physiology, v.144, p.307-313, 1994. https://doi.org/10.1016/S0176-1617(11)81192-2 